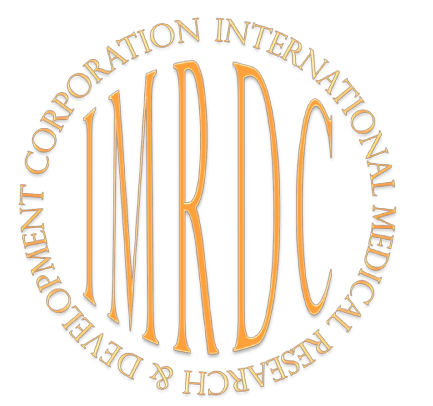

\title{
Biotechnology
}

\section{Optical Barrier for Microbiological Control after a Sterilization Process}

\author{
Bruno Pereira de Oliveira, Kate Cristina Blanco*, Javier A. Jurado, \\ Vanderlei Salvador Bagnato \\ University of São Paulo, São Carlos Institute of Physics, São Carlos, São Paulo, Brazil
}

\begin{abstract}
An optical barrier (OB) may eliminate the entrance of aerosol generated by clinical procedures in sterilization devices. The OB is a new alternative for sterilizing medical and dental instruments. The objective of the study was to evaluate the action of the $\mathrm{OB}$ on the entrance of bacteria into an autoclaving system and to correlate the time and distance of exposure. To test the configuration of the device, we used Escherichia coli. A lamp utilized in this instrument was low pressure with a wavelength around $254 \mathrm{~nm}$. A homogenous distribution of light around the door was observed by the Inventor 2015 software. Microbiological tests showed efficient bacterial elimination at a distance of $8 \mathrm{~cm}$ from OB. The results show that the use of the OB radiation for 30 minutes guarantees the non-entry of microorganisms into the sterilized environment. The use of the OB may be recommended to maintain the surface of sterile materials for long periods of time. (International Journal of Biomedicine. 2017;7(2):135-137.)
\end{abstract}

Key Words: Optical barrier • bacteria $\bullet U V$ light $\bullet$ Escherichia coli $\bullet$ biomedical device

\section{Introduction}

Cross-contamination is a problem in the healthcare area which requires considerable attention, given that is necessary to promote the security of the patient during medical procedures and to eliminate the possibility of transmitting infectious diseases. Thus, a sterilization process is necessary, and one device used to kill microorganisms present in materials used in medical offices is the autoclave. ${ }^{(1)}$

Medical offices have a very high concentration of microorganisms in the air. Currently, the healthcare professional puts medical instruments into packages after applying the protocol to eliminate biological organisms (spores, bacteria, fungi, etc.). However, a lot of different concepts and methods for sterilizing materials can be found in the literature. One example present in the discussion is the use of ultraviolet (UV) light. Nevertheless, several factors need to be addressed, such as the procedure for cleaning equipment, existing and new materials to be used, and the development of new methods and instruments. ${ }^{(2-8)}$

*Corresponding author: Kate Cristina Blanco. University of São Paulo, São Carlos Institute of Physics, São Carlos, São Paulo, Brazil.E-mail: blancokate@gmail.com
A common problem in dental autoclave devices is the increased probability of direct contact of microorganisms present in the environment with the interior of the autoclave after the door is opened, consequently decreasing the shelflife of instruments already sterilized. The purpose of this study was to assess the effectiveness of a new adaptation of sterilization devices, an optical barrier UV to remove or inactivate microbial aerosol.

\section{Materials and Methods}

\section{Lamp UV device system}

The device contains one low-pressure mercury UV lamp (HNS-4W-OSRAM) with an emission wavelength of approximately $254 \mathrm{~nm}$ (Fig. 1), fixed by two supports and surrounded by a polymer curtain that focuses the UV rays towards the front slot of the autoclave (Fig. 2).

The autoclave is equipped with a sensor located on the side of the door such that the lamp system is switched on or off when the door is opened or closed, respectively.

\section{Simulation of the curtain}

A design of the prototype was made using Inventor 2015 software (Autodesk Inc.). In addition, an optical device 
was developed with a light curtain designed to direct the UV light straight down. A simulation was done using TracePro 6.0 software (Lambda Research Corporation) in order to evaluate the distribution of the radiance in the front side of the autoclave.
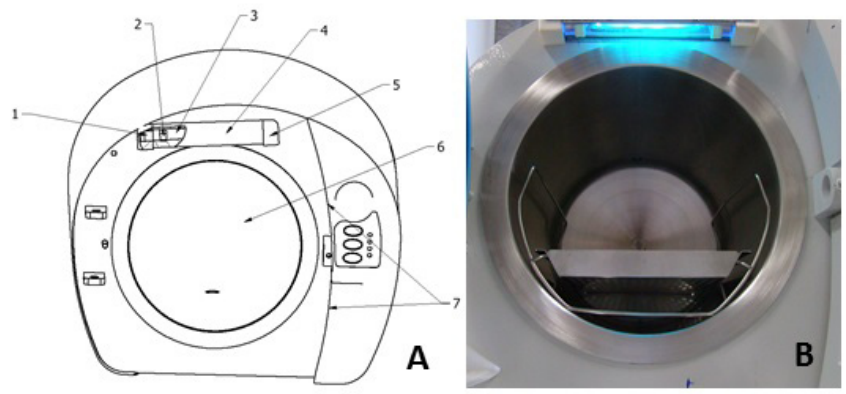

Fig. 1. A) Front layout of the optical curtain: 1) Connector cap of UV lamp; 2) Reel for stabilizers a device on wall; 3) Quartz tube and a UV Lamp inside; 4) Polymer structure for direct a rays; 5) Protector of the cap; 6) Autoclave tank; 7) Sensor for control switches. B) Photograph of a tray device in the autoclave.
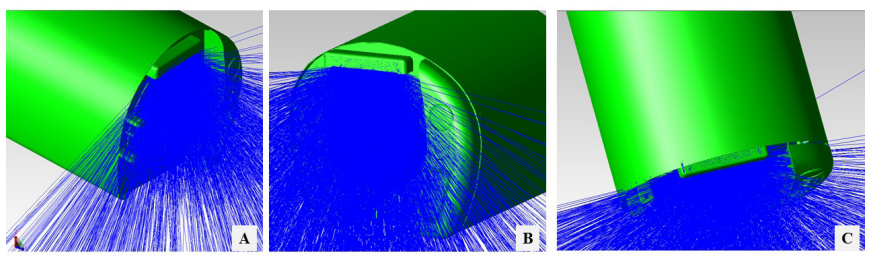

Fig. 2. Curtain and distribution of light on the autoclave door in wavelength $254 \mathrm{~nm}$ with OSRAM UV lamp $4 \mathrm{~W}$; A) left side view; B) Right side view; C) top view.

\section{Microbial strains and growth conditions}

The microorganism used for the in vitro study was Escherichia coli (ATCC 25922). E. coli was cultivated in Brain Heart Infusion Broth at $37{ }^{\circ} \mathrm{C}$ for $18 \mathrm{~h}$. The microbial inoculum was centrifuged (1000xg for $15 \mathrm{~min}$ ) and resuspended in buffered phosphate saline. The initial inoculum was adjusted for $10^{7}$ cells $/ \mathrm{mL}$ at $600 \mathrm{~nm}$. For the analysis of the antimicrobial effect of optical barrier, plates containing E. coli $\left(10^{7}\right.$ cells $\left./ \mathrm{mL}\right)$ were positioned below the optical barrier and $5 \mathrm{~cm}$ from the barrier.

\section{Results and Discussion}

We used an optical simulation in order to describe the behavior of light emitted from the UV lamp, and to characterize the device after mechanical construction. Figure 3 shows the radiance distribution in the area of the autoclave door. This model is suited for device simulation purposes of microbial decontamination in this study.

The different views in the figure above show the uniform distribution of the UV light around the opening of the tank. A second step in the simulation involves evaluating the intensity and distribution of the light in three distinct areas of the autoclave. The results are shown on Figure 4.
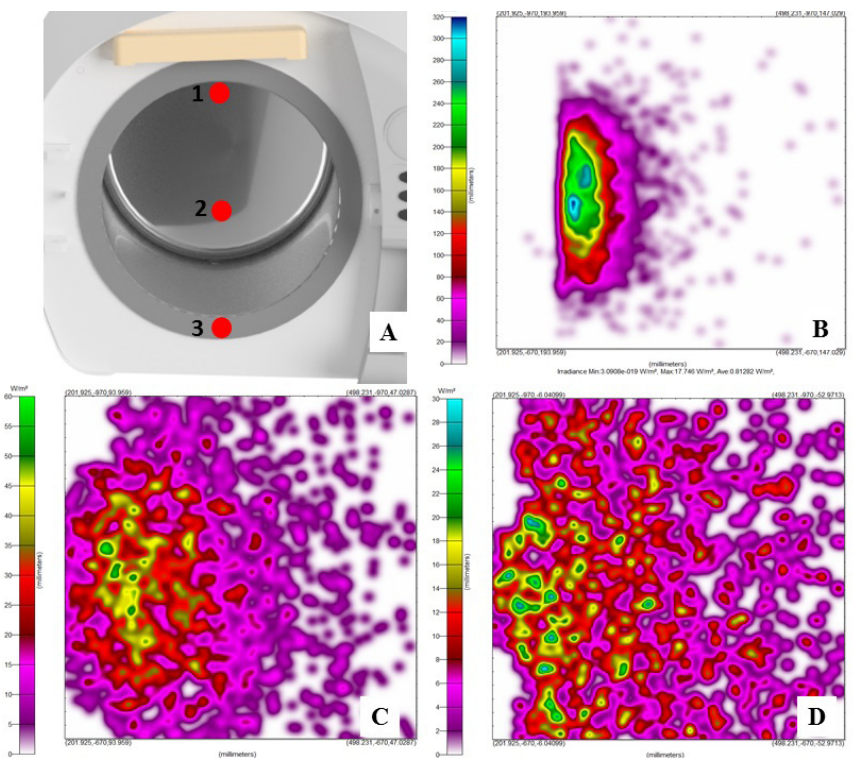

Fig. 3. (A) Intensity measurement locations. (B) Intensity distribution on Location 1. (C) Intensity distribution on Location 2. (D) Intensity distribution on Location 3.

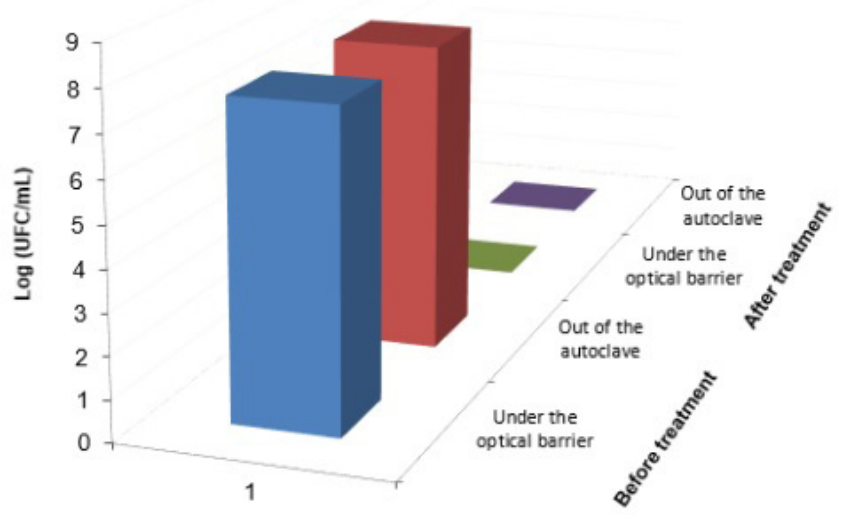

Fig. 4. Antimicrobial response of UV barrier during 30 min. Plate with E. coli located on door area directly under UV light and plate in front of autoclave during 60 min of UV barrier.

The results of the simulation show us that there is an even distribution of UV-C light in the front of the tank; however, microbiological experiments were performed for proof of concept. First, we present the results for plates with E. coli with initial concentration of $10^{7} \mathrm{CFU} / \mathrm{mL}$.

The results show two different positions of the plates. Plate 1 is located directly under the light and Plate 2 is located out on the front of the autoclave. It is possible to verify that there is a reduction in the microbial agent in the plate directly exposed to light and within $5 \mathrm{~cm}$ on the front of the autoclave. 
Another characterization performed consisted of measuring the time necessary for the microorganisms to increase in the autoclave with the light on and off. The results show the time necessary for recontamination of materials present in the autoclave after having been processed (Table 1).

Table 1.

Results of bacterial presence over time. The X denotes detection of colonies.

\begin{tabular}{|l|c|c|c|c|c|}
\hline \multirow{2}{*}{ Condition } & \multicolumn{5}{|c|}{ Time (min) } \\
\cline { 2 - 6 } & 9 & 10 & 20 & 30 & 60 \\
\hline Light off & $\mathrm{X}$ & $\mathrm{X}$ & $\mathrm{X}$ & $\mathrm{X}$ & $\mathrm{X}$ \\
\hline Light on & & & & $\mathrm{X}$ & $\mathrm{X}$ \\
\hline
\end{tabular}

There is immediate detection of microorganisms with the UV light off; however, with the UV light on, the minimum time necessary for detection is $30 \mathrm{~min}$.

UV light present at the front of the autoclave constitutes a practical method for establishing a barrier for microorganisms present in the environment and also for preventing recontamination of packages or instruments after the autoclaving process.

Our experimental setup shows that it is possible to adapt a barrier onto the autoclave. Future studies would consist of establishing different criteria for optimization of the device and testing different positions of the sensors. There are many UV light devices tested for viruses and bacteria by USEPA, the National Science Foundation, and WHO. ${ }^{(9)}$

UV radiation induces mutations in the pyrimidine dimers of DNA. ${ }^{(10)}$ Distribution of light intensity shows that there is an even distribution of UV-C wavelengths in the front of the tank, which explains the oxidative damage in bacteria. Thus, it is possible that the air could be sterilized with total bacteria death within a margin of $15 \mathrm{~cm}$ of the optical barrier.

\section{Competing interests}

The authors declare that they have no competing interests.

\section{Acknowledgements}

The authors acknowledge the support provided by FAPESP (São Paulo Research Foundation) - grant number: 2013 / 07276-1 (CEPOF - CEPID Program).

\section{References}

1. Block SS. Disinfection, sterilization, and preservation. Philadelphia, Pa.; London: Lippincott Williams \& Wilkins; 2001.

2. Bagnato VS. Novas Téenicas Opticas Para As Áreas De Saúde. In: Livraria da Fisica Ed. Português; 2008.

3. Sinha RP, Häder DP. UV-induced DNA damage and repair: a review. Photochem Photobiol Sci. 2002;1(4):225-36.

4. Santos ER, Correia FC, Wang SH, Hidalgo P, Fonseca FJ, Junior ECB, de Andrade AM. Reator de UV-Ozônio com lâmpada a vapor de mercúrio a alta pressão modificada para tratamento superficial de óxidos transparentes condutivos utilizados em dispositivos poliméricos eletroluminescentes. 2010. Quim Nova;33(8):1779-83.

5. Bialka KL, Demirci A. Efficacy of pulsed UV-light for the decontamination of Escherichia coli O157:H7 and Salmonella spp. on raspberries and strawberries. J Food Sci. 2008;73(5):M201-7. doi: 10.1111/j.1750-3841.2008.00743.x. 6. Oguma K, Kita R, Takizawa S. Effects of Arrangement of UV Light-Emitting Diodes on the Inactivation Efficiency of Microorganisms in Water. Photochem Photobiol. 2016; 92(2):314-317. doi: 10.1111/php.12571.

7. Hoben HJ, Somasegaran P. Comparison of the Pour, Spread, and Drop Plate Methods for Enumeration of Rhizobium spp. in Inoculants Made from Presterilized Peat. Appl Environ Microbiol. 1982;44(5):1246-7.

8. Gilchrist JE, Campbell JE, Donnelly CB, Peeler JT, Delaney JM. Spiral plate method for bacterial determination. Appl Microbiol. 1973;25(2):244-52.

9. Abd-Elmaksoud S, Naranjo JE, Gerba CP. Assessment of a portable handheld UV light device for the disinfection of viruses and bacteria in water. Food Environ Virol. 2013;5(2):87-90. doi: 10.1007/s12560-013-9103-7.

10. Kujundzic E, Matalkah F, Howard CJ, Hernandez M, Miller SL. UV air cleaners and upper-room air ultraviolet germicidal irradiation for controlling airborne bacteria and fungal spores. J Occup Environ Hyg. 2006;3(10):536-46. 